\title{
Strikebreaking and the Labor Market in the United States, 1881-1894
}

\author{
JOSHUA L. ROSENBLOOM
}

Using data from a sample of over 2,000 individual strikes in the United States from 1881 to 1894 this article examines geographic, industrial, and temporal variations in the use of strikebreakers and the sources from which they were recruited. The use of strikebreakers was not correlated with the business cycle and did not vary appreciably by region or city size, but employers located outside the Northeast or in smaller cities were more likely to use replacement workers recruited from other places. The use of strikebreakers also varied considerably across industries, and was affected by union authorization and strike size.

$\mathrm{T}$ he forces determining wages and working conditions in American labor markets were radically altered in the decades after the Civil War. Improvements in transportation and communication increased the ability of workers to migrate in response to differential opportunities and encouraged employers in labor-scarce areas to recruit workers from relatively more labor-abundant regions. As local labor markets became increasingly integrated into broader regional and national labor markets during the late nineteenth century, competitive pressures on wages and working conditions grew, and the scope for local variations in the terms of employment declined. ' In many industries these pressures were further compounded by technological changes that encouraged the increasingly fine division of labor and enabled employers to replace skilled craftworkers with semiskilled operatives or unskilled laborers. ${ }^{2}$

The impact of these developments on American workers was profound. Broader labor markets and technological changes expanded employment opportunities for some workers, but for others they undermined efforts to increase wages and improve working conditions. ${ }^{3}$ The increasing elasticity

The Journal of Economic History, Vol. 58, No. 1 (Mar. 1998). (C) The Economic History Association. All rights reserved. ISSN 0022-0507.

Joshua L. Rosenbloom is Associate Professor, Department of Economics, University of Kansas, Lawrence, KS 66045 and Research Associate, National Bureau of Economic Research.

I am especially indebted to Gerald Friedman for making available to me his sample of strike data drawn from the reports of the Commissioner of Labor. I thank Thomas Weiss, Bill Sundstrom, and Price Fishback for their comments. The suggestions of seminar participants at Yale, Wesleyan, Tufts, and Columbia Universities, SUNY Stony Brook, the University of North Carolina, the University of Georgia, and the NBER-DAE program are also gratefully acknowledged. Greg Stutes and Janie Phelps provided able research assistance, for which I thank them. This research has also benefited from a fellowship provided by the Hall Center for the Humanities at the University of Kansas.

'Commons et al., History, pp. 43-44; Lebergott, Manpower, pp. 132-36; and Rosenbloom, "Was There a National Labor Market."

${ }^{2}$ Gordon et al., Segmented Work, pp. 112-16.

${ }^{3}$ Whatley ("African-American Strikebreaking") argued, for example, that strikebreaking provided an important source of opportunities for African-Americans. Based on accounts of 141 incidents of 
of labor supply made it difficult for local unions to advance wages. Having won higher wages and more control over piece rates in 1881, for example, carpenters in St. Louis found that "our advances in wages would soon be lost through the influx of men from cities where wages were lower. Day after day men came from other states where wages were $\$ 1.75$ to $\$ 2 .{ }^{, 4} \mathrm{~A}$ skilled butcher in Chicago put the matter more bluntly, observing simply that the threat of being replaced by less-skilled workers was "the club held above our heads at all times." The effects of increasing competition went beyond the purely economic however, as a letter to a local newspaper from a coal miner in Ohio's Hocking Valley made clear. When new arrivals displaced long-time employees in the 1870 s he wrote, the displaced workers experienced "about the same emotions that an ordinary person would if robbed of his home."

One of the most visible and contentious manifestations of the increasing competitive pressures in American labor markets in the late nineteenth century was the widespread use of strikebreakers. ${ }^{7}$ The aggregate statistics reproduced in Table 1 show that between 1881 and 1900 employers hired over half a million replacement workers. This amounts to close to 10.8 percent of the 4.7 million workers who went on strike in this period. Of these replacements, over 40 percent were brought to the location of the strike from somewhere else, suggesting the important role that employers played in expanding local labor supply. Employers' ability to replace striking workers has long been regarded by labor historians as one of the most potent weapons available to them in their efforts to defeat labor's demands for improvements in employment conditions. Philip Foner argued, for example, that "the failure of a great number of strikes in the cotton textile, mining, iron and steel, cigar, railroad, and other industries must be attributed in no small measure to the ability of employers to make use of unskilled labor obtained from the labor exchanges and steamship companies as strikebreakers."

African-American strikebreaking between the Civil War and the 1930s, he found that strikebreaking helped to encourage migration out of the South, and opened doors to industries and occupations from which African-Americans had previously been barred by racial discrimination.

${ }^{4}$ Ulman, Rise, chap. 3. Quotation from Tygiel, "Tramping Artisans," p. 366.

${ }^{5}$ Quoted in Tuttle, "Labor Conflict," p. 412.

${ }^{6}$ Quoted in Gutman, "Reconstruction," p. 247.

${ }^{7}$ Although the widespread use of strikebreakers in this period has sometimes been attributed to the large volume of immigration in the late nineteenth century, Ehrlich ("Immigrant Strikebreaking") argued that recent immigrants were no more likely to serve as strikebreakers than were the native-born or members of older immigrant groups. Based on articles and letters published in the National Labor Tribune, a major labor weekly in the late nineteenth century, he attributed the frequency of strikebreaking in the late nineteenth century to the generally abundant labor supply in this period, rather than the volume of immigration per se.

${ }^{8}$ Foner, History, p. 17. 
TABLE 1

AGGREGATE STRIKE STATISTICS, $1881-1900$

\begin{tabular}{|c|c|c|c|c|c|c|}
\hline \multirow[b]{2}{*}{ Year } & \multirow[b]{2}{*}{$\begin{array}{c}\text { Number } \\
\text { of } \\
\text { Strikes }\end{array}$} & \multirow[b]{2}{*}{$\begin{array}{c}\text { Number } \\
\text { on } \\
\text { Strike }\end{array}$} & \multicolumn{2}{|c|}{ New Employees } & \multicolumn{2}{|c|}{$\begin{array}{c}\text { New Employees } \\
\text { Brought from } \\
\text { Other Places }\end{array}$} \\
\hline & & & Number & $\begin{array}{c}\text { Percentage } \\
\text { of } \\
\text { Strikers } \\
\end{array}$ & Number & $\begin{array}{c}\text { Percentage } \\
\text { of New } \\
\text { Employees }\end{array}$ \\
\hline 1881 & 471 & 101,070 & 10,957 & 10.8 & 3,949 & 36.0 \\
\hline 1882 & 454 & 120,857 & 11,353 & 9.4 & 5,356 & 47.2 \\
\hline 1883 & 478 & 122,198 & 11,434 & 9.3 & 4,450 & 38.9 \\
\hline 1884 & 443 & 117,313 & 11,833 & 10.1 & 4,324 & 36.5 \\
\hline 1885 & 645 & 158,584 & 19,077 & 12.0 & 7,224 & 37.9 \\
\hline 1886 & 1,432 & 407,152 & 39,854 & 9.8 & 12,932 & 32.4 \\
\hline 1887 & 1,436 & 272,776 & 39,549 & 14.5 & 18,173 & 46.0 \\
\hline 1888 & 906 & 103,218 & 16,700 & 16.2 & 5,237 & 31.4 \\
\hline 1889 & 1,075 & 205,068 & 16,725 & 8.2 & 6,802 & 40.7 \\
\hline 1890 & 1,833 & 285,900 & 31,034 & 10.9 & 12,393 & 39.9 \\
\hline 1891 & 1,717 & 245,042 & 34,115 & 13.9 & 17,378 & 50.9 \\
\hline 1892 & 1,298 & 163,499 & 25,847 & 15.8 & 13,492 & 52.2 \\
\hline 1893 & 1,305 & 195,008 & 21,907 & 11.2 & 11,017 & 50.3 \\
\hline 1894 & 1,349 & 505,049 & 75,092 & 14.9 & 35,198 & 46.9 \\
\hline 1895 & 1,215 & 285,742 & 24,726 & 8.7 & 9,221 & 37.3 \\
\hline 1896 & 1,026 & 183,813 & 13,289 & 7.2 & 5,128 & 38.6 \\
\hline 1897 & 1,078 & 332,570 & 16,108 & 4.8 & 7,344 & 45.6 \\
\hline 1898 & 1,056 & 182,067 & 19,064 & 10.5 & 7,335 & 38.5 \\
\hline 1899 & 1,797 & 308,267 & 36,303 & 11.8 & 16,171 & 44.5 \\
\hline 1900 & 1,779 & 399,656 & 31,590 & 7.9 & 11,331 & 35.9 \\
\hline Total & 22,793 & $4,694,849$ & 506,557 & 10.8 & 214,445 & 42.3 \\
\hline
\end{tabular}

Source: U.S. Bureau of Labor, Sixteenth Annual Report, pp. 340-43.

Despite the importance that has conventionally been attributed to strikebreaking there has been little systematic analysis of this aspect of late- nineteenth-century labor conflict. Rather, most discussions have concentrated on a small number of highly visibly or contentious incidents, such as the great railway strike of 1877 and the Homestead strike of 1892 . Recently, however, several studies have taken a more quantitative approach to the issue of strikebreaking. As part of her research on the determinants of union membership, Debbie Mullin examined factors influencing the propensity to use replacement workers in a sample of 395 strikes in Illinois between 1881 and $1886 .{ }^{9}$ She found that the propensity to use replacement workers increased with city size and the duration of the strike, but decreased with the number of strikers. She also noted some differences across industries and occupations, finding that unskilled workers were more likely to be replaced, whereas strikers in the building trades, printing, and cooperage faced a lower risk of replacement. Looking at the impact of state labor laws on strike activity, Janet Currie and Joseph Ferrie found that the legal environment had strong

\footnotetext{
${ }^{9}$ Mullin, "Porous Umbrella."
} 
but "sometimes surprising" effects on the use of strikebreakers. ${ }^{10}$ Analyzing data on over 12,000 strikes in 13 states in the Northeast and North Central regions they found that laws legalizing unions and banning blacklists-both apparently prolabor in their intentions - had the perverse effect of increasing the probability that strikebreakers would be used, but that the use of strikebreakers was less likely in states that had passed laws establishing maximum hours for any group of male workers.

This article uses data from a random sample of over 2,000 individual strikes between 1881 and 1894 drawn from reports compiled by the U.S. commissioner of labor to extend these recent findings by examining how geographic and industrial variations in labor market conditions affected employers' propensity to use strikebreakers and the sources from which they recruited these replacements. ${ }^{11}$ In addition to providing the opportunity to systematically explore variation in the use of strikebreakers, the disaggregated data collected by the Bureau of Labor underscore the impact that strikebreaking had on late-nineteenth-century labor conflict. The data show that the use of strikebreakers was remarkably widespread, occurring in more than 40 percent of the strikes in the sample, and that the use of replacement workers had a powerful effect on the likelihood of strike success. ${ }^{12}$ Of those strikes in which replacements were hired, just 21 percent ended successfully, and only 6.3 percent were partially successful. In contrast, when replacements were not hired, 63 percent of strikes were successful, and another 9.8 percent were partially successful. ${ }^{13}$

The data reveal several interesting regularities in the use and recruitment of strikebreakers. First, contrary to Herbert Gutman's hypothesis that the stronger support for labor in small communities made it more difficult for employers to use strikebreakers, the propensity to use strikebreakers did not vary systematically by either city size or region. ${ }^{14}$ This result is, however,

\footnotetext{
${ }^{10}$ Currie and Ferrie, "Strikes."

"These data were originally collected by Gerald Friedman who has generously made them available to me.

${ }^{12}$ In comparison, Cramton and Tracy report that between 1985 and 1989 replacement workers were employed in just 11 percent of strikes involving 1,000 or more workers, and 17 percent of smaller strikes.

${ }^{13}$ The classification of strikes as successful, partially successful, or failed was performed by the Bureau of Labor investigators who gathered the strike data. They based their judgments on a comparison of the objectives of the strike and its outcome. The impact of strikebreaking on strike success is equally pronounced after conditioning on a wide range of other factors likely to affect the probability of strike success, including industry, location, establishment size, union authorization, and the number of strikers.

${ }^{14}$ One way in which community support for workers' demands could manifest itself was in community resistance to the importation of replacement workers. "Although the mill owners in large cities such as St. Louis, Indianapolis, and Cincinnati found it easy to bring in new workers from outside," according to Gutman, ("Worker's Search," p. 4l) "it was another story in small towns. They could easily hire new hands in Pittsburgh, Philadelphia, and other eastern cities, but the social environment. . made it difficult to keep these men." Because workers often sought to dissuade strikebreakers verbally or to
} 
consistent with evidence from other sources indicating the increasing geographic integration of labor markets in this period. Although the use of strikebreakers was not affected by city size or region, where these replacements came from did vary systematically with locational characteristics. Employers in smaller communities, and in locations outside the Northeast were much more likely to have used replacements brought from other places, suggesting that employer recruitment of labor was an important factor in promoting the geographic mobility of labor. Second, there was substantial variation in the use of replacements across industries. Employers were most likely to use strikebreakers in transportation, printing and publishing, and food processing and meatpacking and were least likely to hire replacements in construction and mining. Third, although there is no indication of any relationship between aggregate economic fluctuations and the use of strikebreakers, it does appear that employers were more likely to turn to replacements in the years immediately following the massive upheavals of 1886. Finally, the data indicate that strikebreaking was less likely to occur in union-authorized strikes after 1886 , suggesting that organized labor was either becoming more effective in controlling geographic mobility, or that unions were becoming more adept at picking those fights that they had a high probability of winning.

\section{STRIKES AND LABOR RELATIONS IN THE LATE NINETEENTH CENTURY}

To contemporaries, the 1880 s and early 1890 s appeared to be an era of unprecedented turbulence in the history of labor relations. Labor journalist John Swinton described the mid-1880s as "revolutionary." In an 1887 report the New York Bureau of Labor Statistics noted that "the year 1886 has witnessed a more profound and far more extended agitation among the members of organized labor than in any previous year in the history of our country." 15 There is no comprehensive quantitative evidence on strike activity before 1881 , but based on a mixture of qualitative and quantitative indicators, David Montgomery has identified the 1870 s as a crucial turning point in the nature of labor conflict. ${ }^{16}$ Prior to the mid-1840s, according to Montgomery, strikes were rare, and riots were the primary vehicle for the

\footnotetext{
block their way into factories or mines, there was always the potential for violence, and the leanings of local law enforcement and militia forces could tip the balance in such confrontations either way. Brecher (Strike!, pp. 6-7) argues that it was precisely this sort of difference in community attitudes that explains why during the Great Railroad Strike of 1877 employers were able to replace striking workers in Baltimore, but failed to do so in Martinsburg, West Virginia. Bennett and Earle ("Geography") interpreted an inverse relationship between strike rates and population for communities with populations of less than 85,000 as partially confirming Gutman's hypothesis, but examination of strikebreaking would appear to be a more direct way of testing his conjecture.

is Both quoted in Foner, History, p. 11.

${ }^{16}$ Montgomery, "Strikes in Nineteenth-Century America."
} 
expression of working-class discontent. In the three decades after 1845 strikes spread out geographically and industrially, but for the most part they remained spontaneous and primarily defensive actions prompted by employer-initiated wage cuts, or the effects of rapid inflation on real wage levels. Beginning sometime in the 1870s, however, the extent and nature of strike activity shifted perceptibly. Increasingly strike objectives shifted from defensive responses to employer actions toward the achievement of recognition of labor's right to bargain collectively over wages and work rules.

The causes of this transition were undoubtedly complex, but there is little question that the rapid pace of economic change in the decades after the Civil War was an important factor contributing to increasing strike activity. Because strikes are ex post inefficient, most economic models assume that they occur because workers and employers do not have access to the same information about firm profitability or the costs that a strike will impose. ${ }^{17}$ The increasing competition in the labor market during the late nineteenth century, resulting from greater geographic integration, together with shocks to supply and demand caused by the emergence of big business and the spread of organized labor, disrupted existing employment relationships and created considerable uncertainty about the relative bargaining power of workers and employers.

Beginning in the 1870s the introduction of capital- and scale-intensive production processes across a wide range of industries and the development of new vertically integrated business organizations serving national markets transformed the manufacturing sector. ${ }^{18}$ Some sense of the transformation is conveyed by the rapid growth in the size and capital intensity of manufacturing establishments at this time. Between 1870 and 1900 the average number of employees per establishment more than doubled in 11 of 16 manufacturing industries. These averages, however, mask the growth of truly large establishments. In 1870 the McCormick plant in Chicago, with an employment of 400 to 500 workers, was considered one of the largest in the nation. By 1900 there were 1,063 establishments with employment of from 500 to 1,000 workers, and an additional 443 employing more than 1,000 workers. ${ }^{19}$ Capital accumulation was proceeding even more rapidly. Between 1879 and 1899 the real value of capital per worker in manufacturing more than doubled. ${ }^{20}$

The increasing scale and capital intensity of manufacturing were often associated with a greater division of labor and the mechanization of pro-

\footnotetext{
${ }^{17} \mathrm{Strikes}$ are inefficient because, whatever the final outcome, both sides could have been better off if they had reached this solution without the costs of foregone production and earnings caused by a strike. See Kennan, "Economics."

${ }^{18}$ Chandler, Visible Hand.

${ }^{19}$ Nelson, Managers, pp. 4-5.

${ }^{20}$ U.S. Bureau of the Census, Historical Statistics, series P-5 and P-123, pp. 666, 685.
} 
cesses previously performed by skilled artisans. Some accounts have emphasized the deskilling nature of late-nineteenth-century technological change, but the consequences of technological change were often complex. ${ }^{21}$ Skill has a variety of different dimensions, and the division of labor could as easily increase skill requirements as decrease them, as David Montgomery's study of machinists at this time clearly illustrates. ${ }^{22}$ Moreover, as Andrew Dawson has shown, between 1870 and 1910 the number of skilled workers grew at least as fast as the total labor force, while the ratio of skilled to unskilled wages was rising - hardly what one would expect if deskilling technological change were reducing employers' demand for skilled workers. ${ }^{23}$

The impact of changes in technology and business organization were not, however, confined only to employees in rapidly expanding firms. As large manufacturers consolidated national markets, smaller more traditional firms faced increasingly intense competition in product markets. Responding to these changes, they sought to increase the intensity of work effort or to cut wages to remain competitive with larger, more efficient producers. ${ }^{24}$

Paralleling the transformation of the manufacturing sector was a marked growth of organized labor. The trade union movement in the United States can be traced back to at least the 1830s, but until the post-Civil War period most labor unions remained transitory organizations, forming during prosperous periods, and collapsing during hard times. It was not until the $1860 \mathrm{~s}$ that the first successful national unions were formed. ${ }^{25}$ Beginning in the late 1870s with several highly publicized successes won by the Knights of Labor, union membership climbed rapidly. Although the Knights of Labor proved unable to sustain this enthusiasm after the mid-1880s, membership in craft unions affiliated with the AFL continued to grow throughout the late nineteenth century.

Although employers and workers were generally aware of the changes in market integration, business structure, and labor organization taking place around them, it was difficult for them to assess how these changes might affect their bargaining power. In the late $1860 \mathrm{~s}$, for example, officials at the McCormick reaper works in Chicago were aware of the influx of European immigrants, but uncertain about the relative costs and benefits of replacing their existing labor force. In an 1867 letter Leander McCormick wrote: "I have thought. . . whether it would not be well to employ an agent to send us [immigrants] as I have seen that [there] are large numbers arriving. ..." But there is no evidence that this effort was pursued, suggesting that the cost of

\footnotetext{
${ }^{21}$ Gordon et al., Segmented Workers; and Brown and Philips, "Craft Labor."

${ }^{22}$ Montgomery, "Strikes of Machinists."

${ }^{23}$ Dawson, "Paradox."

${ }^{24}$ Currie and Ferrie, "Strikes," p. 3.

${ }^{25}$ Ulman, Rise, pp. 3-7; and Commons et al., History, pp. 43-44.
} 
recruiting immigrants proved greater than initially anticipated. Later, in the 1880 s, the McCormicks did attempt to replace striking iron molders with the assistance of their dealers. Although a number of men accepted train tickets to Chicago, the firm had great difficulty retaining any of them. "Out of the lot of men you sent us yesterday," they wrote to one dealer in Des Moines, Iowa, "but two of them showed up in Chicago. . . the balance having deserted along the way." To another dealer they complained: "the gentleman you sent us as a molder. . . did not remain over an hour or two until he packed his valise and skipped."26

A gap between workers' and employers' perceptions of their respective bargaining power is also evident in the 1890 strike of leather workers in Lynn, Massachusetts. According to John Cumbler's account of this conflict, the workers believed that because of the general prosperity of the industry and the value of their skills, employers would quickly concede to their demands. The employers on the other hand, were determined not to give up any of their control over the workplace, and believed that the cost of breaking the union would be smaller than the cost of accepting their employees' demands. ${ }^{27}$

In the atmosphere of uncertainty that characterized late-nineteenth-century labor relations, workers and employers found themselves frequently at odds. The resulting conflicts offer a valuable window on the changing terrain of labor relations at the time. By studying systematic variations in the use of strikebreakers (and other strike outcomes) it is possible to gain new insight about the impact of changing economic conditions on the labor market.

\section{THE STRIKE DATA}

Prompted by the rapidly increasing level of labor conflict during the first half of the 1880s, the U.S. commissioner of labor in 1886 initiated an effort to compile a comprehensive listing of all strikes that had occurred since 1881. Agents of the Bureau of Labor combed newspapers and other publications to compile a list of strikes and lockouts for these years. Then field agents were dispatched to investigate each conflict. Whenever possible these agents interviewed representatives of both sides in the conflict so as to corroborate the facts they had gleaned from published accounts. A subsequent report extended the collection of data from 1886 through the middle of 1894. Together these two reports include data on more than 12,000 strikes. ${ }^{28}$ Previous analysts have regarded the Bureau of Labor's strike data

${ }^{26}$ Ozanne, Century, pp. 7, 15.

${ }^{27}$ Cumbler, "Labor," pp. 403-04.

${ }^{28}$ U.S. Bureau of Labor, Third Annual Report and Tenth Annual Report. Although the bureau continued to collect data on strikes after 1894 , subsequent publications provided only aggregate figures by state, industry, and year, rather than listing individual strikes, making it impossible to extend the analysis beyond this year. 
as both "comprehensive and reliable." ${ }^{29}$ Recently, however, Gary Bailey has raised questions about the completeness of their coverage. ${ }^{30}$ Based on a comparison between local newspapers in Terre Haute, Indiana, and the strike statistics for 1881 to 1894 , he found that of 34 strikes mentioned in the local press, only about half were included in the Bureau of Labor's tabulation. Although this finding does raise some concern about the comprehensiveness of the data, it poses less of a problem for studies such as this one that explore the relationships between various aspects of individual strikes.

For each strike in its tabulation the bureau reported, among other facts, the industry and occupation of the workers on strike; whether the strike was authorized by a union; the number of workers on strike; employment, wages, and hours before the strike; the duration of the conflict; its cause(s) and outcome(s), including the number (if any) of replacement workers hired; and the number of such workers brought from other locations. Unfortunately the data do not provide any additional information about the sources from which outside strikebreakers were recruited, or when during the strike they were hired.

This article employs a random sample of 2,070 strikes drawn from the strike data. ${ }^{31}$ The strike statistics are augmented with population data drawn from the censuses of 1880,1890 , and 1900 and a measure of the skill level of the workers involved based on the occupational titles reported by the Bureau of Labor..$^{32}$ Table 2 summarizes selected characteristics of the strikes for the sample, as well as for those strikes in which strikebreakers were hired, and those in which strikebreakers were brought from other places. The table clearly documents the quantitative significance of strikebreaking during the late nineteenth century. Replacement workers were hired in 851 strikes ( 41 percent of the total), and in these instances employers hired an average of nearly 63 replacement workers. If anything these figures are likely to understate employers' efforts to use replacements. Striking workers and their supporters often attempted to prevent strikebreakers from taking up their jobs through persuasion and the threat or use of force. Only where employers were in fact successful in putting replacements to work would they appear in the strike statistics. The use of outside strikebreakers was also

\footnotetext{
${ }^{29}$ Montgomery, "Strikes in Nineteenth-Century America," p. 86. The data collection effort is described in U.S. Bureau of Labor, Third Annual Report, Tenth Annual Report, and Sixteenth Annual Report. For additional discussion of the data see P. K. Edwards, Strikes; Friedman, "Strike"; Card and Olson, "Bargaining Power"; and Currie and Ferrie, "Strikes."

${ }^{30}$ Bailey, "Commissioner."

${ }^{31}$ The data consist of a one-in-five random sample of strikes between 1881 and 1886 , and a one-inten random sample of strikes between 1887 and 1894.

32 Population data were available for cities with populations in excess of 25,000 in 1900 . I estimated the population between census years by assuming a constant rate of population increase. I determined skill levels based on a comparison of occupational titles with the classification scheme elaborated in Alba Edwards, "Social-Economic Grouping."
} 


\begin{tabular}{|c|c|c|c|}
\hline & All strikes & $\begin{array}{l}\text { Strikes with } \\
\text { Replacements }\end{array}$ & $\begin{array}{l}\text { Strikes with } \\
\text { Replacements } \\
\text { Brought from } \\
\text { Elsewhere }\end{array}$ \\
\hline$N$ & 2070 & 851 & 269 \\
\hline Average employment before strike & 408.42 & 579.75 & 1060.33 \\
\hline Average number on strike & 202.91 & 282.81 & 633.79 \\
\hline Average duration in days & 21.50 & 28.27 & 39.45 \\
\hline Average number of replacements hired & 25.77 & 62.68 & 129.85 \\
\hline $\begin{array}{l}\text { Average number of replacements brought from } \\
\text { elsewhere }\end{array}$ & 12.33 & 29.13 & 94.81 \\
\hline Fraction authorized by union & 0.657 & 0.632 & 0.695 \\
\hline Fraction fully successful & 0.460 & 0.217 & 0.178 \\
\hline Fraction partially successful & 0.088 & 0.074 & 0.093 \\
\hline Fraction in cities with 250,000 or more population & 0.356 & 0.326 & 0.175 \\
\hline Fraction in cities with less than 25,000 population & 0.453 & 0.424 & 0.542 \\
\hline Fraction in Northeast region & 0.639 & 0.636 & 0.501 \\
\hline Fraction in North Central region & 0.290 & 0.287 & 0.394 \\
\hline Fraction for increase in wages & 0.373 & 0.368 & 0.323 \\
\hline Fraction for reduction in hours & 0.076 & 0.082 & 0.082 \\
\hline Fraction involving skilled workers & 0.368 & 0.374 & 0.415 \\
\hline $\begin{array}{l}\text { Fraction in which replacement workers were hired } \\
\text { Fraction in which replacement workers were }\end{array}$ & 0.411 & 1.00 & 1.00 \\
\hline brought from elsewhere & 0.130 & 0.316 & 1.00 \\
\hline
\end{tabular}

Source: Strike sample data described in text.

quite common, occurring in nearly one-third of the strikes in which any replacement workers were hired.

It is also apparent that strikes in which replacements were hired differed in a number of ways from those in which they were not. The use of replacements appears to have been associated with larger strikes and larger establishments. There is also a positive correlation between the use of strikebreakers, especially from outside the community, and strike duration; but without knowing when during the strike replacements were hired, it is impossible to determine whether longer duration was a cause or a consequence of the use of replacements. These differences are all even more pronounced for the sample of strikes in which replacements were brought from other places.

\section{THE INCIDENCE OF STRIKEBREAKING}

An employer's decision whether to use replacement workers presumably depends upon his calculation of the balance between the costs and expected benefits of recruiting strikebreakers. Once a strike has begun the employer can either recruit replacements or wait for an acceptable settlement to be negotiated without hiring replacements. ${ }^{33}$ Suppose that the probability of

${ }^{33}$ See Cramton and Tracy, "Use," for a more extensive discussion of the inclusion of the use of strikebreaking within standard bargaining models of strikes. 
ending the strike on the employer's terms is $P(S, X)$, where $S$ is the number of replacements employed $(S \geq 0), X$ is a vector of exogenous variables, and $P$ is an increasing function of $S$. If the employer wins the strike, the net benefit realized through lower labor costs is $L(Y)$, where $Y$ is a vector of exogenous variables. The cost of recruiting replacements can be denoted by $C(S, Z)$, where $Z$ is a vector of exogenous variables, and costs are presumably an increasing function of the number of replacements recruited. The employer's objective is to choose $S$ to maximize

$$
B(S ; X, Y, Z)=P(S, X)^{*} L(Y)-C(S, Z)
$$

subject to the constraint that $S$ must be non-negative. Solving this maximization problem results in the following reduced-form expression relating the optimal number of replacements to other strike characteristics

$$
\begin{aligned}
S^{*} & =G(X, Y, Z), \text { when } G(X, Y, Z)>0 \\
& =0 \text { otherwise }
\end{aligned}
$$

Using data on strikebreaking and other strike characteristics drawn from the Bureau of Labor's strike reports it is possible to estimate this relationship.

The first task is to identify the exogenous variables that affected the costs and expected benefits of hiring strikebreakers. Despite increasing geographic integration in this period, some regional differences in labor supply may have persisted, affecting the costs of hiring replacements. The bulk of European immigration passed through port cities in the Northeast, and this may have lowered the cost of recruiting replacements in this region. On the other hand, the use of convict leasing in the South may have lowered the cost of obtaining strikebreakers in this region. In an imperfectly integrated labor market, employers in smaller places would also face a smaller supply of potential strikebreakers, and hence a higher cost of recruiting replacements. If the residents of smaller communities were more likely to feel a sense of solidarity with striking workers, as Herbert Gutman and others have speculated, this effect would be reinforced by the greater community opposition to strikebreaking in smaller places. ${ }^{34}$ It also seems possible that the supply of potential strikebreakers would vary with aggregate economic fluctuations, increasing as the unemployment rate rose.

The issue of controlling migratory labor was central to the emergence in this period of national trade unions. ${ }^{35}$ To the extent that unions were effective in achieving this goal, the supply of strikebreakers would be smaller in union-authorized strikes, and hence the cost of hiring replacements would be higher. The effect of union authorization seems likely to have increased

\footnotetext{
${ }^{34}$ Gutman, "Worker's Search."

${ }^{35}$ Ulman, Rise, chaps. 2-3; and Commons et al., History, pp. 307-12.
} 
after the mid-1880s as national unions affiliated with the American Federation of Labor became more adept at using strike funds to discipline local unions and maintain solidarity among striking workers. Gerald Friedman has found that after 1886 the shift in union strategy did indeed increase the likelihood of success for union-authorized strikes. ${ }^{36}$

The cost of recruiting strikebreakers would also depend on the extent of training that they required and on the amount of hostility that introducing new workers might induce among current employees. To some extent these factors are likely to be a function of the skill level of the striking workers, but they may also have been at least partly functions of industry characteristics. Finally, the costs of recruiting replacements would be expected to rise as the number of workers on strike increased.

Employers in this period often evidenced a profound hostility to unions, which figured in their calculation of the benefits of recruiting strikebreakers. The bitter Homestead conflict of 1892, for example, was motivated by Andrew Carnegie's desire to break the union. ${ }^{37}$ Similarly, when leather workers in Lynn, Massachusetts, went on strike in 1890, the manufacturers agreed to fight the union and bring the open shop to the city. ${ }^{38}$ This suggests that the perceived benefits of winning a strike may have been greater when it was authorized by a union than when it was a spontaneous protest. Employers may also have viewed the benefits of winning as greater when the strike was offensive in nature (over issues like wage increases, hours reductions, or work rules), than when it was a spontaneous, defensive response to employer-initiated wage cuts. Because the costs of foregone production imposed by a strike were likely to be an increasing function of establishment size, the benefits of ending a strike should be an increasing function of prestrike employment. The costs imposed by a work stoppage (and hence the benefits of ending it) would also vary across industries depending on the ability of employers to build up inventories in anticipation of a strike, and the potential loss of customers that would follow from a temporary interruption in supplies. In general, this suggests that employers in service industries, and industries with highly perishable products or highly competitive markets would have perceived the benefits of using replacements to be greater. Finally, the expected benefit that employers perceived from recruiting replacements depended not only on the cost saving they anticipated from a successful conclusion of the strike, but also on the probability that this event would occur. Other things equal, it seems likely that that probability of winning would be a decreasing function of the number of workers on strike.

\footnotetext{
${ }^{36}$ Friedman, "Strike," pp. 13-17.

${ }^{37}$ Foner, History, pp. 208-09.

${ }^{38}$ Cumbler, "Labor," pp. 403-04.
} 
Because of the large number of strikes in which no strikebreakers were used, ordinary least squares is not an appropriate method to estimate the relationship described in equation 2 . To allow for the possibility that the function $G$ is discontinuous at zero, I employed a two stage estimation procedure. In the first stage I estimated a probit equation in which the dependent variable takes the value one if any strikebreakers were used, and zero otherwise. In the second stage I estimated by ordinary least squares the determinants of the number of replacement workers hired (measured in logs). To control for possible sample selection bias in this equation I included the inverse Mills's ratio calculated from the first stage probit estimates. ${ }^{39} \mathrm{Be}$ cause the reasons for a strike's occurrence are likely to affect an employer's willingness to use strikebreakers, but not the number of replacements needed to defeat the strike, I excluded strike cause effects from the second-stage estimation of the determinants of the number of replacements hired. ${ }^{40}$

To capture locational differences in the supply of strikebreakers, zero-one indicator variables for three regions and four city-size classes are included. To control for the effects of skill and industry on the costs and benefits of employing strikebreakers, an indicator variable for highly skilled workers and a set of indicators for 14 of the most common industries in the data are included. Indicators variables for each year are included to control for macroeconomic fluctuations that might have affected the supply of potential strikebreakers. To control for the impact of differences in strike causes, indicator variables are included for defensive strikes and for strikes initiated by labor demands for higher wages or shorter hours. The excluded category is strikes over work rules. Indicators are also included to measure the effects of union-authorization and possible changes in this effect after 1886. Finally,

\footnotetext{
${ }^{39}$ The need to correct for sample selection arises because the OLS regression is restricted to only those observations for which $S$ is nonzero. The problem can be seen most clearly by considering an empirical analog of equation 2, which adds an error term $u$ to reflect the impact of unobserved characteristics. Letting $i$ index individual observations and assuming that the function $G(X, Y, Z, u)$ can be approximated as linear in its arguments, the model then becomes $S_{i}=a X_{i}+b Y_{i}+c Z_{i}+u_{i}$, where $a, b$, and $c$ are vectors of coefficients. Rearranging terms, it is apparent that the condition $S_{i}>0$ is equivalent to the condition that $u_{i}>-a X_{i}-b Y_{i}-c Z_{i}$. Thus, even if it is assumed that the expected value of $u_{i}$ is zero across the entire sample, this will clearly not be true for the set of strikes for which $S_{i}$ is nonzero, violating one of the underlying assumptions of OLS model. Heckman, "Sample Selection Bias," has shown, however, that this problem can be resolved by adding an estimate of the expected value of $u_{i}$ to the regression. This additional regressor is the ratio $\Phi\left(Z_{i}\right) / \Phi\left(-Z_{j}\right)$ where $\phi$ and $\Phi$ are, respectively, the density and distribution functions of the standard normal variable, and $Z_{i}$ is an estimate of $u_{i}$ divided by its standard error derived from the probit estimates over the full sample. The ratio $\phi / \Phi$ is the inverse of Mills's ratio. See, also Madala, Limited-dependent and Qualitative Variables, pp. 158-59, for additional discussion and references.

${ }^{40} \mathrm{An}$ alternative approach to estimating equation 2 would be to use the Tobit model, but this imposes the unnecessary restriction that the slope coefficients be continuous at zero (see Maddala, LimitedDependent and Qualitative Variables, chap. 6). In terms of signs and relative magnitudes Tobit estimates (not reported here) closely resemble the results obtained from the first-stage probit estimation. As will be seen later, however, the impact of several variables on the number of replacements hired appears to be quite different from that on employers' propensity to use replacements.
} 
measures of prestrike employment and the number of workers on strike are included to control for scale effects.

Table 3 reports the results of estimating both equations. Because the coefficient estimates of the probit equation are not directly interpretable they are transformed into slope coefficients. For discrete variables the table reports the implied effect on the predicted probability of using replacement workers that would result from changing the variable's value from zero to one when all the other independent variables are set at their sample means. For the continuous variables, the table reports the implied partial derivative of the probability of using replacement workers with respect to that variable, where the derivative is evaluated at the sample means of the independent variables.

The probit estimates indicate that locational effects on the propensity to use replacement workers appear quite limited. None of the regional effects is large in magnitude or statistically significant. Several of the city-size variables are statistically significant, but the direction of these effects is inconsistent, and not especially large. Employers in cities with populations of 250,000 or more appear to have been somewhat less likely to use replacements, whereas those in the next largest size class - those with populations between 100,000 and 250,000 - were somewhat more likely to use replacements. On the basis of these estimates there is no indication that employers in smaller places faced higher costs of recruiting replacements. In contrast to the limited impact of location, industry effects were much more pronounced. Employers in transportation, printing, and food preparation were 10 to 20 percentage points more likely to use replacement workers than were employers in the excluded category of miscellaneous industries. Evaluated at the predicted probability of using replacements of 40 percent, this implies that the use of replacements was one-quarter to one-half more likely in these industries. In view of the relative successes of organized labor in the building trades it is perhaps not surprising that the use of replacements was 12 percentage points less likely in construction than in miscellaneous industries. Of greater note, however, the data indicate that despite numerous accounts of strikebreaking and violence aimed at strikebreakers in mining, employers in this industry were nearly 18 percentage points less likely to use replacements than in the excluded category. If there is a pattern here, it appears to be that employers in industries with perishable products were more likely to use replacements, other things equal, than were those in industries where the durability of products reduced the short-run costs of strike-caused interruptions in production. After controlling for industry there does not appear to be any significant effect of skill levels on the probability of strikebreaking. It may be that this variable is poorly constructed, however, and industry effects are already capturing the important variations in skill level.

None of the strike cause effects is large or statistically significant, but the 
variable for union authorization after 1886 enters with a negative and statistically significant effect. This suggests that either unions were becoming better at choosing which struggles they were likely to win or union control of mobility was becoming more effective in limiting strikebreaking during the latter 1880 s and early 1890 s and that these effects outweighed any impact of employer antipathy toward unions in this period. Both of the scale variables enter the regression significantly, and with the expected signs. ${ }^{41} \mathrm{Em}$ ployers were more likely to turn to replacements the larger the establishment, or the smaller the number of workers on strike. The magnitudes of the two coefficients suggest that effects of establishment size were somewhat stronger than those of the number of strikers, so that holding constant the fraction of workers on strike, the use of replacements was more common in large establishments than in small ones.

Only a few of the year effects are statistically significant, and their pattern does not suggest any consistent cyclical effects on employers' propensity to use strikebreakers. On the other hand the large positive effects in 1886, 1887 , and 1888 suggest that employers may have increased their use of replacement workers in the wake of the pronounced unrest that culminated in the strike wave of 1886 .

The ordinary least squares estimates of the determinants of the number of replacements hired indicate that the strongest explanatory factors are scale effects. The log of the number of strikers is highly significant and suggests that employers attempted to replace a little over 40 percent of their striking workers. Holding the number of workers on strike constant, the number of replacements hired was also increasing with establishment size. The coefficient on this variable implies that every 10 percent increase in establishment size increased the number of replacements by 2.4 percent.

Several other interesting patterns also emerge after controlling for these scale factors. First, the city-size effects suggest that when employers in midsized cities turned to replacements they hired larger numbers of them than was true of employers in cities with populations either under 25,000 or greater than 249,999 . Only two of the industry effects enter the regression significantly, but both are in industries in which the propensity to replace was higher than usual. In both transportation and printing and publishing, not only were employers more likely to use replacement workers, but when they used replacements they tended to hire more of them. Finally, the insignificant coefficient on the inverse Mills's ratio indicates that the hypothesis of no sample selection bias cannot be rejected at standard confidence levels.

\footnotetext{
${ }^{41}$ The coefficients imply that a one standard deviation increase in the number of employees before the strike would raise the probability of using replacement workers by 7 percentage points, whereas a one standard deviation increase in the number of workers on strike would lower the probability of using replacements by 4.6 percentage points.
} 
TABLE 3

DETERMINANTS OF THE USE OF REPLACEMENTS AND THE LOG OF THE NUMBER OF REPLACEMENTS HIRED

\begin{tabular}{|c|c|c|c|c|c|c|}
\hline \multirow[b]{2}{*}{ Variable } & \multirow[b]{2}{*}{ Mean } & \multirow[b]{2}{*}{$\begin{array}{l}\text { Standard } \\
\text { Deviation }\end{array}$} & \multicolumn{2}{|c|}{$\begin{array}{l}\text { Probit Regression for } \\
\text { Use of Replacements }\end{array}$} & \multicolumn{2}{|c|}{$\begin{array}{l}\text { OLS Regression for } \\
\text { Log (Number of } \\
\text { Replacements) }\end{array}$} \\
\hline & & & Coefficient & $t$-statistic & Coefficient & $t$-statistic \\
\hline \multicolumn{7}{|l|}{ City size effects ${ }^{b}$} \\
\hline $25,000-49,999$ & 0.060 & 0.237 & -0.0042 & -0.087 & 0.3013 & $2.064^{* *}$ \\
\hline $50,000-99,999$ & 0.073 & 0.259 & -0.0077 & -0.169 & 0.4213 & $3.549^{\circ *}$ \\
\hline $100,000-249,999$ & 0.085 & 0.278 & 0.0712 & $1.615^{\circ}$ & 0.3191 & $1.816^{\circ *}$ \\
\hline 250,000 or more & 0.356 & 0.479 & -0.0666 & $-2.365^{* *}$ & -0.1743 & -1.234 \\
\hline \multicolumn{7}{|l|}{ Region effects ${ }^{c}$} \\
\hline North Cèntral & 0.289 & 0.454 & -0.0234 & -0.891 & 0.0107 & 0.120 \\
\hline South & 0.061 & 0.240 & 0.0004 & 0.009 & 0.0429 & 0.326 \\
\hline West & 0.010 & 0.098 & -0.0180 & -0.160 & -1.0183 & $-1.814^{\circ}$ \\
\hline \multicolumn{7}{|l|}{$\begin{array}{l}\text { Industry and occupation } \\
\text { effects }^{\text {d }}\end{array}$} \\
\hline Transportation & 0.054 & 0.226 & 0.1036 & $1.890^{\circ}$ & 0.6605 & $2.877^{\cdots *}$ \\
\hline Construction & 0.167 & 0.373 & -0.1191 & $-2.7566^{* *}$ & -0.2336 & -1.009 \\
\hline Mining & 0.087 & 0.281 & -0.1784 & $-3.827^{\circ * 0}$ & -0.1353 & -0.360 \\
\hline \multicolumn{7}{|l|}{ Stone quarrying and } \\
\hline \multicolumn{7}{|l|}{ Metals and metalic } \\
\hline goods & 0.094 & 0.292 & -0.0613 & -1.367 & -0.0736 & -0.407 \\
\hline Machinery & 0.022 & 0.146 & -0.0652 & -0.817 & 0.2847 & 1.091 \\
\hline Printing and publishing & 0.032 & 0.176 & 0.1836 & $2.523^{* *}$ & 0.7609 & $2.352^{* *}$ \\
\hline Furniture & 0.033 & 0.178 & 0.0286 & 0.415 & 0.1537 & 0.696 \\
\hline Wooden goods & 0.024 & 0.152 & -0.0091 & -0.117 & 0.1067 & 0.459 \\
\hline Boots and shoes & 0.046 & 0.210 & -0.0383 & -0.656 & -0.2095 & -1.051 \\
\hline Clothing & 0.074 & 0.262 & 0.0449 & 0.889 & -0.0179 & -0.098 \\
\hline Tobacco and cigars & 0.079 & 0.269 & 0.0198 & 0.395 & 0.0547 & 0.324 \\
\hline Glass & 0.021 & 0.143 & -0.1088 & -1.357 & -0.3658 & -1.070 \\
\hline \multicolumn{7}{|l|}{ Food preparation, } \\
\hline canning, butchering & 0.022 & 0.147 & 0.1311 & $1.605^{\circ}$ & 0.1535 & 0.419 \\
\hline Skilled occupation & 0.368 & 0.482 & 0.0413 & 1.354 & 0.1058 & 0.863 \\
\hline \multicolumn{7}{|l|}{ Strike cause effects ${ }^{c}$} \\
\hline Wage increase & 0.373 & 0.484 & -0.0417 & -1.574 & & \\
\hline Hours reduction & 0.076 & 0.265 & 0.0180 & 0.383 & & \\
\hline Defensive & 0.147 & 0.355 & -0.0434 & -1.219 & & \\
\hline \multicolumn{7}{|l|}{$\begin{array}{l}\text { Strike characteristics } \\
\text { effects }\end{array}$} \\
\hline $\log ($ no. of employees) & 4.539 & 1.580 & 0.0435 & $3.597^{\cdots \cdots}$ & 0.2424 & $3.070^{* * *}$ \\
\hline $\log$ (no. of strikers) & 3.691 & 1.538 & -0.0299 & $-2.412^{* *}$ & 0.4181 & $6.531^{\cdots \cdots}$ \\
\hline $\begin{array}{l}\text { Authorized by union } \\
\text { Authorized by union, }\end{array}$ & 0.657 & 0.475 & 0.0176 & 0.468 & 0.1594 & 1.249 \\
\hline \multirow{2}{*}{\multicolumn{7}{|c|}{ Year effects ${ }^{f}$}} \\
\hline & & & & & & \\
\hline 1882 & 0.043 & 0.202 & 0.0917 & 1.209 & 0.0362 & 0.135 \\
\hline 1883 & 0.048 & 0.213 & 0.1769 & $2.430^{\circ *}$ & 0.5321 & 1.500 \\
\hline 1884 & 0.065 & 0.207 & 0.0484 & 0.649 & 0.1919 & 0.768 \\
\hline 1885 & 0.065 & 0.246 & 0.0124 & 0.182 & 0.1742 & 0.719 \\
\hline 1886 & 0.173 & 0.378 & 0.0688 & 1.160 & -0.0101 & -0.043 \\
\hline
\end{tabular}


TABLE 3 -contiued

\begin{tabular}{|c|c|c|c|c|c|c|}
\hline \multirow[b]{2}{*}{ Variable } & \multirow[b]{2}{*}{ Mean } & \multirow[b]{2}{*}{$\begin{array}{l}\text { Standard } \\
\text { Deviation }\end{array}$} & \multicolumn{2}{|c|}{$\begin{array}{l}\text { Probit Regression for } \\
\text { Use of Replacements } \mathrm{s}^{\mathrm{a}}\end{array}$} & \multicolumn{2}{|c|}{$\begin{array}{l}\text { OLS Regression for } \\
\text { Log (Number of } \\
\text { Replacements) }\end{array}$} \\
\hline & & & Coefficient & $t$-statistic & Coefficient & $t$-statistic \\
\hline 1887 & 0.081 & 0.237 & 0.1001 & 1.392 & 0.2943 & 0.973 \\
\hline 1888 & 0.050 & 0.219 & 0.1435 & $1.807^{\circ}$ & 0.3787 & 1.147 \\
\hline 1889 & 0.060 & 0.238 & 0.0723 & 0.953 & 0.2366 & 0.842 \\
\hline 1890 & 0.098 & 0.297 & 0.0381 & 0.540 & -0.1025 & -0.393 \\
\hline 1892 & 0.074 & 0.263 & 0.0725 & 0.994 & -0.1451 & -0.536 \\
\hline 1893 & 0.072 & 0.259 & 0.0712 & 0.970 & -0.1057 & -0.389 \\
\hline 1894 & 0.048 & 0.215 & 0.0926 & 1.170 & 0.3058 & 1.088 \\
\hline Constant & & & & & -1.4010 & -1.277 \\
\hline Inverse Mills's ratio & & & & & 1.2110 & 1.293 \\
\hline$N$ & & & 2045 & & 838 & \\
\hline $\mathrm{Chi}^{2}$ & & & 117.29 & & & \\
\hline$R^{2}$ & & & & & 0.507 & \\
\hline
\end{tabular}

- Statistically significantly different from zero at the 10 percent level.

* Statistically significantly different from zero at the 5 percent level.

-.. Statistically significantly different from zero at the 1 percent level.

${ }^{a}$ Coefficients are reported as the partial derivatives of the probability with respect to each variable, evaluated at the sample mean values of the other independent variables. For zero-one categorical variables the coefficient shows the change in probability for a discrete change in that variable from zero to one. The $t$-statistics reported are calculated using the original probit parameters and their corresponding standard errors.

${ }^{b}$ Omitted category is cities with population under 25,000 .

${ }^{c}$ Omitted category is Northeast.

d Omitted category is all other industries

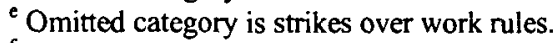

${ }^{f}$ Omitted category is 1881 .

Note: $t$-statistics are computed using heteroscedasticity-corrected standard errors. The observed probability of strikebreaking is 0.4098 , and the predicted probability is 0.4058 .

Source: Strike sample data described in the text.

\section{THE RECRUITMENT OF STRIKEBREAKERS}

That location had little impact on the ability of employers to find replacement workers is consistent with other evidence of the emergence of an increasingly integrated national labor market after the Civil War and suggests that employers in smaller communities were able to tap into broader labor markets with relative ease. ${ }^{42}$ Using information on the recruitment of strikebreakers from other places sheds further light on the role that employer recruitment played in mobilizing labor as well as on the impact that high rates of labor mobility had on labor conflict in this period. Unfortunately the

${ }^{42}$ Rosenbloom, "National Labor Market" and "Extent." Finding that the use of replacement workers did not vary appreciably across locations is a necessary but not sufficient condition for the existence of labor market integration. Because I cannot determine the sources from which strikebreakers were recruited it is not possible to directly assess the geographic scope of markets that this finding implies. On the other hand, integration does imply that employers would face similar costs of recruiting replacements, independent of location. 
TABLE 4

DETERMINANTS OF THE USE OF REPLACEMENTS BROUGHT FROM OTHER PLACES AND LOG OF THE NUMBER OF REPLACEMENTS BROUGHT FROM OTHER PLACES

\begin{tabular}{|c|c|c|c|c|}
\hline \multirow[b]{2}{*}{ Variable } & \multicolumn{2}{|c|}{$\begin{array}{l}\text { Probit Regression for Use of } \\
\text { Outside Replacements }\end{array}$} & \multicolumn{2}{|c|}{$\begin{array}{c}\text { OLS Regression for } \\
\text { Log(Number of Outside } \\
\text { Replacements) }\end{array}$} \\
\hline & Coefficient & $t$-statistic & Coefficient & $t$-statistic \\
\hline \multicolumn{5}{|l|}{ City size effects ${ }^{\mathrm{b}}$} \\
\hline $25,000-49,999$ & 0.0509 & 0.689 & -0.0423 & -0.211 \\
\hline $50,000-99,999$ & -0.0865 & -1.521 & 0.2283 & 0.833 \\
\hline $100,000-249,999$ & -0.1345 & $-2.637^{* * *}$ & -0.4381 & -1.339 \\
\hline 250,000 or more & -0.2619 & $-6.734^{* *}$ & -0.6523 & -1.603 \\
\hline \multicolumn{5}{|l|}{ Region effects $^{c}$} \\
\hline North Central & 0.2094 & $5.156^{\circ \cdots}$ & 0.4177 & 1.513 \\
\hline South & 0.1011 & 1.346 & 0.3081 & 1.446 \\
\hline West & 0.1197 & 0.650 & 0.2856 & 0.888 \\
\hline \multicolumn{5}{|l|}{ Industry and occupation effects ${ }^{d}$} \\
\hline Transportation & 0.0735 & 0.999 & 0.3184 & 1.185 \\
\hline Construction & 0.0364 & 0.507 & -0.1691 & -0.668 \\
\hline Mining & -0.0649 & -0.851 & 0.0822 & 0.256 \\
\hline Stone quarrying and cutting & 0.1973 & $1.919^{\circ}$ & 0.0559 & 0.151 \\
\hline Metals and metalic goods & 0.0446 & 0.645 & -0.2622 & -0.907 \\
\hline Machinery & 0.0881 & 0.812 & 0.5567 & 1.317 \\
\hline Printing and publishing & 0.3736 & $3.701^{\cdots \cdots}$ & 0.1538 & -0.313 \\
\hline Furniture & -0.0714 & -0.630 & -0.8814 & $-1.852^{\circ}$ \\
\hline Wooden goods & -0.2251 & $-2.537^{* * *}$ & -0.5916 & -0.866 \\
\hline Boots and shoes & 0.1304 & 1.454 & -0.5039 & -1.330 \\
\hline Clothing & 0.0411 & 0.541 & -0.6254 & $-2.023^{* *}$ \\
\hline Tobacco and cigars & -0.0767 & -1.028 & -0.8274 & $-2.844^{* * *}$ \\
\hline Glass & 0.0456 & 0.349 & 0.0831 & 0.165 \\
\hline \multicolumn{5}{|l|}{ Food preparation, canning, } \\
\hline butchering & 0.1228 & 1.082 & 0.5533 & 0.690 \\
\hline Skilled occupation & -0.0103 & -0.226 & -0.2074 & -1.070 \\
\hline \multicolumn{5}{|l|}{ Strike cause effects ${ }^{e}$} \\
\hline Wage increase & -0.0037 & -0.090 & & \\
\hline Hours reduction & 0.0782 & 1.065 & & \\
\hline Defensive & 0.0914 & $1.676^{*}$ & & \\
\hline \multicolumn{5}{|l|}{ Strike characteristics effects } \\
\hline $\log ($ no. of employees) & -0.0236 & -1.321 & 0.0632 & 0.803 \\
\hline $\log ($ no. of strikers) & 0.0881 & $4.658^{* * *}$ & 0.6600 & $5.071^{\cdots * *}$ \\
\hline Authorized by union & 0.1312 & $2.401^{* *}$ & 0.4581 & 1.567 \\
\hline \multicolumn{5}{|l|}{ Authorized by union, } \\
\hline $1887-1894$ & 0.0007 & 0.011 & 0.0427 & 0.161 \\
\hline \multicolumn{5}{|l|}{ Year effects ${ }^{\mathrm{f}}$} \\
\hline 1882 & -0.0303 & -0.288 & -0.3361 & -0.998 \\
\hline 1883 & -0.0515 & -0.536 & -0.2599 & -0.739 \\
\hline 1884 & -0.0030 & -0.030 & 0.2164 & 0.677 \\
\hline 1885 & -0.0853 & -0.890 & -0.5509 & -1.353 \\
\hline 1886 & -0.0811 & -0.972 & -0.3593 & -1.060 \\
\hline 1887 & 0.0558 & 0.508 & -0.0953 & -0.221 \\
\hline 1888 & -0.0241 & -0.207 & -0.2576 & -0.671 \\
\hline 1889 & 0.1534 & 1.253 & -0.2097 & -0.487 \\
\hline 1890 & -0.0471 & -0.441 & -0.8098 & $-1.986^{\circ *}$ \\
\hline 1891 & 0.0741 & 0.659 & -0.0926 & -0.245 \\
\hline
\end{tabular}


TABLE 4 - continued

\begin{tabular}{|c|c|c|c|c|}
\hline \multirow[b]{2}{*}{ Variable } & \multicolumn{2}{|c|}{$\begin{array}{l}\text { Probit Regression for Use of } \\
\text { Outside Replacements } \\
\end{array}$} & \multicolumn{2}{|c|}{$\begin{array}{c}\text { OLS Regression for } \\
\text { Log(Number of Outside } \\
\text { Replacements) }\end{array}$} \\
\hline & Coefficient & $t$-statistic & Coefficient & $t$-statistic \\
\hline 1892 & -0.0602 & -0.574 & -0.6641 & -1.601 \\
\hline 1893 & 0.0727 & 0.631 & -0.2173 & -0.519 \\
\hline 1894 & 0.1020 & 0.809 & -0.2386 & -0.549 \\
\hline Constant & & & -0.6807 & -0.547 \\
\hline Inverse Mills's ratio & & & 0.7727 & 1.109 \\
\hline$N$ & 838 & & 263 & \\
\hline $\mathrm{Chi}^{2}$ & 183.33 & & & \\
\hline$R^{2}$ & & & 0.615 & \\
\hline
\end{tabular}

Statistically significantly different from zero at the 10 percent level.

- Statistically significantly different from zero at the 5 percent level.

"*. Statistically significantly different from zero at the 1 percent level.

${ }^{a}$ Coefficients are reported as the partial derivatives of the probability with respect to each variable, evaluated at the sample mean values of the other independent variables. For zero-one categorical variables the coefficient shows the change in probability for a discrete change in that variable from zero to one. The $t$-statistics reported are calculated using the originally estimated probit parameters and their corresponding standard errors.

${ }^{b}$ Omitted category is cities with population under 25,000 .

c Omitted category is Northeast.

Omitted category is all other industries

${ }^{\mathrm{e}}$ Omitted category is strikes over work rules.

${ }^{f}$ Omitted category is 1881 .

Note: $t$-statistics are computed using heteroscedasticity-corrected standard errors. The probability of bringing replacement workers from elsewhere is estimated using the sample of strikes in which some replacement workers were hired. The observed probability of bringing replacements from elsewhere in this sample is 0.3127 , and the predicted probability is 0.2742 .

Source: Strike sample data described in the text.

strike statistics do not contain information about the sources from which outside strikebreakers were recruited, so it cannot be determined whether replacements were recruited over long distances or were drawn from the immediate environs of the strike. It is clear, however, that by the $1880 \mathrm{~s}$ a well-developed network of employment agencies capable of supplying large numbers of unskilled workers was in operation in major cities, and numerous anecdotal accounts suggest that strikebreakers were in at least some cases recruited over long distances. ${ }^{43}$

The same empirical framework used to analyze employers' decisions to use strikebreakers can be applied as well to consider their choice of whether to seek strikebreakers locally, or to recruit them from more distant locations.

\footnotetext{
${ }^{43}$ Rosenbloom, "Employment Agencies" and "Looking for Work." To cite just a few instances of long-distance recruiting: Cumbler ("Labor," pp. 407, 409) reports that leather manufacturers in Lynn, Massachusetts, advertised in Montreal for replacements, and many of the strikebreakers whom they hired appear to have come form Newark; Tuttle ("Some Strikebreakers") finds that in the Chicago meatpacking strike of 1904 replacements came from as far away as Baltimore; Foner (History, pp. 208-09, 233) reports that in Coer D'Alene, Idaho, mine operators recruited replacements from Duluth, Minnesota; and during the Homestead strike Andrew Carnegie advertised for replacements in newspapers in Boston, St. Louis, and Philadelphia.
} 
Restricting the sample to those strikes in which replacement workers were used, I first estimated a probit equation where the dependent variable takes the value one if any strikebreakers were brought from elsewhere, and then estimated the determinants of the number of replacement workers brought from elsewhere (measured in logs) by ordinary least squares, controlling for sample selection bias. The independent variables used in the two equations are identical to those used in Table 3. The results of estimating these two equations are reported in Table 4.

In contrast to the limited role location played in employers' propensity to use strikebreakers, Table 4 reveals strong and systematic locational effects on the use of outside replacements. Beginning with cities of 50,000 or more population, city-size effects are negative and increasingly large in magnitude as city size increases. Overall, outside replacements were used in about 30 percent of strikes in which any replacements were hired. The estimated citysize effects imply that the probability of using outside replacements was reduced to just 17 percent in cities between 100,000 and 250,000 population, and was less than 5 percent in cities with populations of 250,000 or more. Even after controlling for city size, employers outside the Northeast were substantially more likely to use outside replacements than employers in the Northeast. Because of small sample sizes in the South and West, however, only the coefficient estimate for the North Central region is statistically significant.

The industry effects do not suggest any very clear pattern. Printing and publishing, in which both the propensity to replace and the number of replacements hired were higher than average, was also characterized by a higher propensity to use outside replacements. The propensity to use outside replacements was also higher in stone quarrying and cutting, whereas it was lower than average in wooden goods.

Among the strike characteristics variables, it appears that employers were considerably more likely to recruit replacements from other places in the face of union-authorized strikes than in the case of those without union authorization. This suggests that unions were able to enforce a degree of solidarity locally, but that, as Lloyd Ulman has argued, high rates of geographic mobility in this period posed a significant challenge for local unions' efforts to gain employer recognition, and served as an important impetus in the movement toward the formation of national unions. ${ }^{44}$ The propensity to recruit strikebreakers from other places was also increasing with the number of workers on strike. This variable was also associated with increases in the demand for replacements, suggesting that as the number of replacements desired increased, employers were obliged to look further afield to find sufficient supplies of strikebreakers.

\footnotetext{
${ }^{44}$ Ulman, Rise.
} 
The regression for the number of replacements recruited from outside reinforces the impression that, other things equal, the number of replacements required was an important determinant of employers' need to recruit replacements at a distance. The log of the number of strikers enters with a large and statistically significant effect in this regression. This coefficient implies that a 10 percent increase in the number of workers on strike would increase the number of outside replacements hired by 6.6 percent. Although none of the city-size or regional effects is statistically significant, their signs and relative magnitudes reinforce the impression gleaned from the probit equation that employers in smaller cities and outside the Northeast tended to rely more heavily on outside replacements. In those rare instances when employers in cities with populations over 100,000 turned to outside replacements, the estimated coefficients imply that they used fewer of them than did their counterparts in smaller places. Similarly, when employers outside the Northeast recruited outside strikebreakers they tended to recruit more of them than was true of employers within the Northeast. Finally, the coefficient on the inverse Mill's ratio implies that the hypothesis of no sample selection bias cannot be rejected at standard confidence levels.

\section{CONCLUSION}

During the late nineteenth century increasing labor market integration and technological change made it easier for employers to replace striking workers. Although labor historians have long believed that employers' use of strikebreakers was an important factor undermining organized labor in this period, discussion of strikebreaking has been based largely on evidence drawn from a few highly visible incidents. The individual strike data analyzed in this article confirm earlier impressions of both the ubiquity and significance of strikebreaking for labor relations in the 1880 s and early $1890 \mathrm{~s}$. Strikebreaking was indeed quite common, occurring in over 40 percent of all strikes, and exerted a powerful influence on the chances of strike success.

Beyond this, however, the strike data also offer a number of important insights about variations in the effects of changing labor market conditions on workers in different industries and locations. First, evidence of systematic variation across locations in the recruitment of outside replacements and the absence of any locational effects on employers' propensity to use strikebreakers suggest that neither geographic isolation nor community solidarity provided strikers with much protection against the threat of replacement. The greater propensity of employers to recruit outside strikebreakers in union-authorized strikes further underscores the impact that high rates of geographic mobility in this period had in undermining organized labor's efforts to win recognition in this period. Second, the risk of replacement varied substantially across industries. Industry is a proxy for a wide range 
of possible influences, but it appears that employers were most likely to replace striking workers in industries where the perishability of products made strikes most costly. Third, it appears that after 1886 either the efforts of national trade unions to use strike funds to control mobility among their members were successful in reducing the supply of strikebreakers in unionauthorized strikes, or that the national unions were becoming more adept at selecting those conflicts in which they had the greatest chance of success.

\section{REFERENCES}

Bailey, Gary L. "The Commissioner of Labor's 'Strikes and Lockouts': A Cautionary Note." Labor History 32, no. 3 (1991): 432-40.

Bennett, Sari, and Carville Earle. "The Geography of Strikes in the United States, 1881-1894." Journal of Interdisciplinary History 13, no. 1 (1982): 63-84.

Brecher, Jeremy. Strike! Boston: South End Press, 1972.

Brown, Martin, and Peter Philips. "Craft Labor and Mechanization in Nineteenth-Century American Canning." this JouRnal 46, no. 3 (1986): 743-56.

Card, David, and Craig A. Olson. "Bargaining Power, Strike Durations, and Wage Outcomes: An Analysis of Strikes in the 1880s." Journal of Labor Economics 13, no. 1 (1995): 32-61.

Chandler, Alfred D., Jr. The Visible Hand: The Managerial Revolution in American Business. Cambridge, MA: Harvard University Press, 1977.

Commons, John R., David J. Sappos, Helen L. Sumner, et al. History of Labour in the United States, Vol. 2. New York: Macmillan, 1918.

Cramton, Peter C., and Joseph S. Tracy. "The Use of Replacement Workers in Union Contract Negotiations: The U.S. Experience, 1980-1989." NBER Working Paper no. 5106 (May 1995).

Cumbler, John T. "Labor, Capital, and Community: The Struggle for Power." Labor History 15, no. 3 (1974): 395-415.

Currie, Janet, and Joseph Ferrie. "Strikes and the Law in the U.S., 1881-1894: New Evidence on the Origins of American Exceptionalism." NBER Working Paper, no. 5368 (November 1995).

Dawson, Andrew. "The Paradox of Dynamic Technological Change and the Labor Aristocracy in the United States, 1880-1914." Labor History 20, no. 3 (1979): 325-51.

Edwards, Alba M. "A Social-Economic Grouping of the Gainful Workers in the United States." Journal of the American Statistical Association 28, no. 4 (1933), 377-87.

Edwards, P. K. Strikes in the United States, 1881-1974. Oxford: Basil Blackwell, 1981.

Ehrlich, Richard L. "Immigrant Strikebreaking Activity: A Sampling of Opinion Expressed in the "National Labor Tribune."' Labor History 15, no. 4 (1974), 529-42.

Friedman, Gerald. "Strike Success and Union Ideology: The United States and France, 1880-1914." this JOURNAL 48, no. 1 (1988): 1-26.

Foner, Philip S. History of the Labor Movement in the United States. 2nd ed. Vol. 2: From the Founding of the American Federation of Labor to the Emergence of American Imperialism. New York: International Publishers, 1975.

Gordon, David M., Richard Edwards, and Michael Reich. Segmented Work, Divided Workers: The Historical Transformation of Labor in the United States. Cambridge: Cambridge University Press, 1982.

Gutman, Herbert G. "Reconstruction in Ohio: Negroes in the Hocking Valley Coal Mines in 1873 and 1874." Labor History 3, no. 3 (1962): 243-64. 
"The Worker's Search for Power: Labor in the Gilded Age." In The Gilded Age: A Reappraisal, edited by H. Wayne Morgan, pp. 31-54. Syracuse, NY: Syracuse University Press, 1970.

Heckman, James J., "Sample Selection Bias as a Specification Error." Econometrica 47, no. 1 (1979): 153-61.

Kennan, John. "The Economics of Strikes." In Handbook of Labor Economics. 2 vols., edited by Orley Ashenfelter and Richard Layard, pp. 1091-138. Amsterdam: North-Holland, 1986.

Lebergott, Stanley. Manpower in Economic Growth: The American Record Since 1800. New York: McGraw-Hill, 1964.

Maddala, G. S. Limited-Dependent and Qualitative Variables in Econometrics. Econometric Society Monographs, no. 3. Cambridge: Cambridge University Press, 1983.

Montgomery, David. "Strikes in Nineteenth-Century America." Social Science History 4, no. 1 (1980): 81-104.

"Strikes of Machinists in the United States, 1870-1922." In Strikes, Wars and Revolutions in an International Perspective, edited by Leopold H. Haimson and Charles Tilly, pp. 269-88. Cambridge: Cambridge University Press, 1989.

Mullin, Debbie. "The Porous Umbrella of the AFL: Evidence from Nineteenth-Century State Labor Bureau Reports on the Establishment of American Unions." Ph.D. diss., University of Virginia, 1993.

Nelson, Daniel. Managers and Workers: Origins of the New Factory System in the United States, 1880-1920. Madison: University of Wisconsin Press, 1975.

Ozanne, Robert. A Century of Labor Management Relations. Madison: University of Wisconsin Press, 1967.

Rosenbloom, Joshua L. "Employment Agencies and Labor Exchanges Before the First World War: An Examination of the Methods of Labor Market Adjustment." Photocopy, Department of Economics, University of Kansas, 1991.

"Looking for Work, Searching for Workers: U.S. Labor Markets after the Civil War." Social Science History 18, no. 3 (1994): 377-403.

"Was There a National Labor Market at the End of the Nineteenth Century? New Evidence on Earnings in Manufacturing." this JouRNAL 56, no. 3 (1996): 626-56.

" "The Extent of the Labor Market in the United States, 1850-1914." Social Science History (forthcoming, 1998).

Tuttle, William M., Jr. "Some Strikebreakers' Observations of Industrial Warfare." Labor History 7, no. 2 (1966): 193-96.

"Labor Conflict and Racial Violence: The Black Worker in Chicago, 1894-1919." Labor History 10, no. 3 (1969): 408-32.

Tygiel, Jules. "Tramping Artisans: The Case of the Carpenters in Industrial America." Labor History 22, no. 3 (1981): 348-76.

Ulman, Lloyd. The Rise of the National Trade Union. Cambridge, MA: Harvard University Press, 1955.

U.S. Bureau of Labor. Third Annual Report of the Commissioner of Labor. Washington, DC: GPO, 1888.

Tenth Annual Report of the Commissioner of Labor. Washington, DC: GPO, 1896. Sixteenth Annual Report of the Commissioner of Labor. Washington, DC: GPO, 1901.

U.S. Bureau of the Census. Historical Statistics of the United States, Colonial Times to 1970, Bicentennial Edition. Washington, DC: GPO, 1975.

Whatley, Warren C. "African-American Strikebreaking from the Civil War to the New Deal." Social Science History 17, no. 4 (1993): 525-58. 